\title{
Comparison between cylindrical and prismatic lithium-ion cell costs using a process based cost model
}

\author{
Rebecca E. Ciez $\%$ J.F. Whitacre* + , \\ $\dagger$ Department of Engineering \& Public Policy, $\$$ Department of Materials Science and \\ Engineering, Carnegie Mellon University, 5000 Forbes Avenue, Pittsburgh, Pennsylvania 15213, \\ United States
}

* Corresponding Author, Tel: (412) 268-5548; Fax: 412-268-3757; E-mail:

whitacre@andrew.cmu.edu 


\begin{abstract}
The relative size and age of the US electric vehicle market means that a few vehicles are able to drive market-wide trends in the battery chemistries and cell formats on the road today. Three lithium-ion chemistries account for nearly all of the storage capacity, and half of the cells are cylindrical. However, no specific model exists to examine the costs of manufacturing these cylindrical cells. Here we present a process-based cost model tailored to the cylindrical lithiumion cells currently used in the EV market. We examine the costs for varied cell dimensions, electrode thicknesses, chemistries, and production volumes. Although cost savings are possible from increasing cell dimensions and electrode thicknesses, economies of scale have already been reached, and future cost reductions from increased production volumes are minimal. Prismatic cells, which are able to further capitalize on the cost reduction from larger formats, can offer further reductions than those possible for cylindrical cells.
\end{abstract}

Keywords: lithium-ion, production cost, cathode chemistry, cylindrical cell

\title{
1. Introduction
}

As the price of lithium-ion batteries has fallen in recent years, they have made the leap from high-end electronics applications to bulk energy storage applications, including electric vehicles and backup electricity storage for on- and off-grid systems. However, while the costs are no longer prohibitively expensive, systems using lithium-ion batteries are still more expensive than other alternatives, and are still far from being low enough to enable economically competitive renewable-based baseload power. [1]

In the years since lithium-ion batteries were first introduced in these new applications, there have been many advancements and changes in both battery chemistry and manufacturing technology. These advancements have already led to substantial cost reductions, but 
understanding the future evolution of costs is important to inform future applications and policies. There is also renewed interest as battery and electric vehicle manufacturers propose to significantly expand their production capacity.

Because of the significance of manufacturing costs, models of the production costs of lithium-ion batteries have been developed. The most notable model is the BatPaC model developed by Argonne National Lab. [2,3] Using multiple battery pack configurations and lithium-ion chemistries, the model determines the cost per $\mathrm{kWh}$, allowing for increases in production volume from the baseline rate of 100,000 packs year ${ }^{-1}$. Additional work has been done to analyze some of the specific steps of pouch cell manufacturing outlined in the BatPaC model. Wood et al find that reducing the duration of solid-electrolyte interphase (SEI) formation and replacing expensive solvents can reduce the costs of manufacturing of small batches of batteries [4]. Both Wood et al [4] and Sakti et al [5] find that there are also cost savings when electrode thicknesses are increased, increasing the energy storage capacity of each cell.

All of these models produce cost estimates that are largely in line with current industry prices. Nykvist and Nilsson compiled stated predictions, news reports, and journal articles to analyze trends in lithium-ion cell- and pack-level prices [6]. Their data is reproduced in Figure 1, along with BatPaC estimates (using the May 2015 version), the estimates from Sakti et al [5], and expert predictions collected by Sakti et al. [7]

However, since these models and analyses were introduced, the lithium-ion battery market has shifted. 419,000 battery vehicles (BEVs) and plug-in hybrid electric vehicles (PHEVs) were sold between 2010 and the end of 2015. The number of vehicles sold and the storage capacity of these vehicles varies significantly. The Tesla Model S, one of the most popular electric vehicles, has a battery pack that varies between 75 and $90 \mathrm{kWh}$, much larger 
than the $10.5 \mathrm{kWh}$ average pack size for PHEVs and double the $42 \mathrm{kWh}$ average for BEVs. These packs also use cylindrical lithium-ion cells, a departure from the prismatic cells examined in previous models. Electric vehicle sales and pack sizes also impact the most commonly used lithium-ion chemistries. Lithium Nickel Cobalt Aluminum Oxide (NCA) is the most common chemistry, accounting for half of the storage capacity on the road today, and Lithium Manganese Oxide (LMO) and Lithium Nickel Manganese Cobalt Oxide (NMC) account for approximately a quarter each. Other chemistries have been used in niche applications (predominantly in California compliance cars and early electric vehicle models), but have largely been phased out. The supplementary information provides full details on vehicle sales and associated battery storage.

Also as a result of these sales trends, on a per kWh basis, the majority of lithium-ion batteries on the road in the US today are cylindrical. To date, manufacturing process research and cost models have focused exclusively on prismatic cells, and there is no specific model to address the costs of manufacturing cylindrical cells. To address the disparity between the current EV battery market and research, we present a process-based cost model specifically adapted for manufacturing cylindrical lithium-ion cells.

The model uses common inputs from the $\mathrm{BatPaC}$ model for the steps that are identical for both prismatic and cylindrical cell manufacturing and accounts for the three chemistries most commonly used in electric vehicles. The model also allows for variations in the cylindrical cell dimensions. We use 18650 cells as a baseline (18 $\mathrm{mm}$ diameter, $65 \mathrm{~mm}$ height), but allow for $10 \%$ increases in cell height and diameter, allowing for a per-cell increase in storage capacity. We also account for variations in the cell electrode thickness. For any combination of parameters, we calculate the manufacturing cost at various production volumes to compare the 
costs between chemistries and determine whether there are additional economies of scale that have not been realized. The manufacturing costs include in-house preparation of cathode active materials, which are commonly purchased at a markup by battery manufacturers.

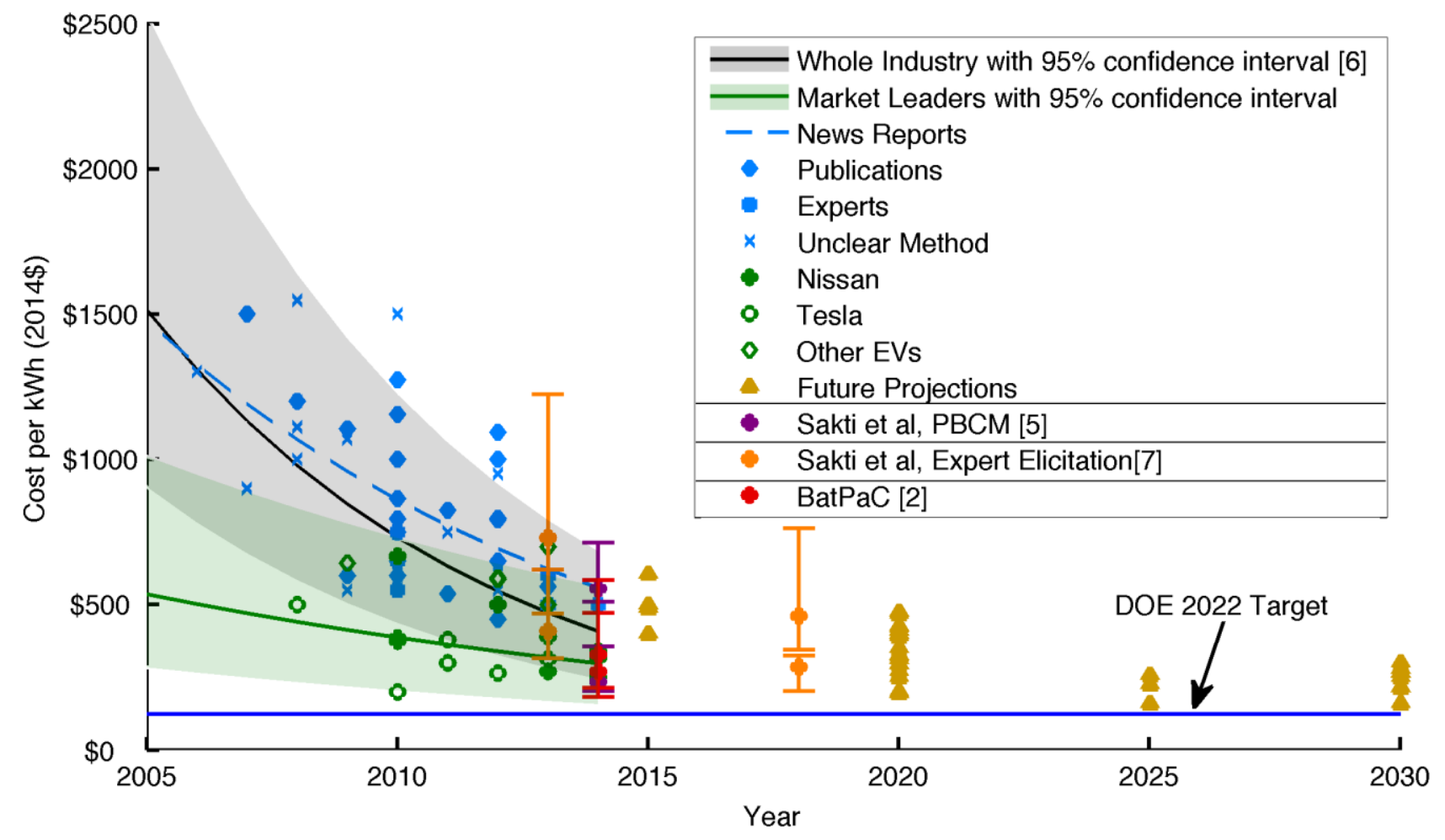

Figure 1: Historical prices and future cost predictions for lithium ion batteries. Estimates include both cell- and pack-level cost assessments, which is reflected in the significant variability in the cost estimates.

\section{Methods}

The model consists of two parts: the first builds a cell based on desired cell dimensions and chemistry, the second computes the per cell and per kWh cost of manufacturing these cells at varying production volumes. 


\subsection{Battery cell model}

The model allows us to specify several parameters about the final form factor of the battery: the chemistry (LMO, NMC, or NCA), the diameter and height of the cells, and the electrode thickness. The upper bounds on the cell height and diameter are based on industryspecified limitations on heat transfer away from the cells. Similarly, the upper bound on the thickness of the electrode is limited by the cylindrical cell geometry. Unlike prismatic cells, where the electrodes are stacked, the electrodes in cylindrical cells must be wound. Since the current collecting foils are coated on both sides, the thickness of each individual coating cannot exceed $100 \mu \mathrm{m}$. Thicker electrode coatings would likely crack when wound because of the very small radius at the center of the cell. Electrode coatings are also somewhat limited by current manufacturing capabilities, as outlined in the interviews conducted by Sakti et al.[8]

Depending on the parameter selections, the model calculates the bill of materials required to construct the battery, and determines the overall storage capacity of each cell. Table 1 lists the user-specified cell parameter selections. The energy storage capacity is determined by the active cathode material in each cell and the cell chemistry's specific energy storage capacity and voltage. Specific internal dimensions were based on a combination of the user specified parameters (namely the electrode thickness and height of the cell) and on published dimensions of the electrode thicknesses of prototype cylindrical cells.[9] The energy stored $(E)$ in each cell is the product of the material voltage $(V)$ and specific storage capacity $(s)$ and the mass of cathode material $(m)$, as shown in equation 1 .

$$
E=V s m
$$

The active material mass depends on the cathode volume $\left(v_{\mathrm{CATH}}\right)$, the density of the final cathode material $\left(\rho_{\text {САTH }}\right)$, and the percentage of active material in the cathode $\left(p_{\mathrm{ACT}}\right)$ (equation 2$)$. 


$$
m=\rho_{C A T H} v_{C A T H} p_{A C T}
$$

The cathode volume is a product of the electrode height $\left(x_{\mathrm{H}}\right)$, cathode length $\left(x_{\mathrm{L}}\right)$, and the total (double-sided) thickness $\left(x_{\mathrm{T}}\right)$ as shown in equation 3.

$$
v_{C A T H}=x_{H} x_{L} x_{T}
$$

The length of the cathode is determined by equation 4 , which accounts for all of the interior volume of the cell, $v_{\text {cell }}$ (assumed to be $85 \%$ of the cell volume calculated from exterior dimensions). Here, we assume that the anode and cathode foils $\left(x_{F}\right)$ and active material coatings $\left(x_{T}\right)$ are of the same thickness and height $\left(x_{H}\right)$. However, the cathode and separators (with thickness $x_{S}$ ) are assumed to be $10 \%$ longer than the anode, in line with the dimensions specified in prototype cells. [9] The separator thickness is doubled to account for the two separators needed for the double-sided coating. The volume available within the cell is then divided by the volume of the electrodes (with varying lengths) and the volume of the separators, as shown in equation 4.

$$
x_{L}=1.1\left(\frac{v_{\text {cell }}}{x_{H}\left(x_{T}+x_{F}+1.1\left(x_{T}+2 x_{S}+x_{F}\right)\right)}\right)
$$

\begin{tabular}{|l|l|}
\hline Parameter & Values \\
\hline Cell Chemistry & LMO $\left(100 \mathrm{mAh} \mathrm{g}^{-1}\right), \mathrm{NMC}\left(200 \mathrm{mAh} \mathrm{g}^{-1}\right), \mathrm{NCA}\left(180 \mathrm{mAh} \mathrm{g}^{-1}\right)$ \\
\hline Cell Dimensions & $18650,18720,20650,20720$ \\
\hline Electrode Thickness & $50,70,100 \mathrm{um}$ \\
\hline
\end{tabular}

Table 1: Cell BOM Parameters examined

\subsection{Cost model}

We model the cell cost using a process-based cost model (PBCM) for each of the steps involved in manufacturing cylindrical lithium-ion cells. This method has been applied to numerous industries, but it originated with the electronics industry, where design for manufacturing is a key concern.[10-12] Sakti et al also applied this method for calculating the cost of prismatic lithium-ion cells.[5] Here, we adapt this cost model to specifically focus on 
cylindrical cells. Figure 2 outlines each of the manufacturing steps included. Those in gray are the same for both cylindrical and prismatic cells. Those in green are specifically for cylindrical cells. The precursor preparation step (in blue) is common to all cell formats, but is not in the scope of the BatPaC model.

The total production cost in a PBCM is determined by summing material, equipment, auxiliary equipment, building, maintenance, labor, energy, and fixed overhead costs. The perunit cost is the sum of these costs divided by the final output. Equipment and building costs are determined using discrete increases in required machinery necessary to produce increased production volumes, accounting for yield losses in the production process. Table 2 shows the facility-wide assumptions, and sensitivity ranges used to calculate the cost of each of the steps. Table 3 shows the equipment, area, and labor requirements for each step. For the steps common to both prismatic and cylindrical cells, these estimates are based on the $\mathrm{BatPaC}$ model, but are adjusted to $2015 \$$. Although the steps listed in Figure 2 are common to manufacturing all of the types of cylindrical cells derived from the cell model, there is equipment customization required for many of the steps depending on the cell electrode dimensions. As a result, the cost of switching a manufacturing process from one type of cell to another is very expensive, and would include not only additional equipment costs (as improperly tooled equipment would need to be replaced, possibly before its recovery period), but would also result lost production time to accommodate the installation. These costs are excluded from our analysis, and we look at the processes for a single cell format throughout.

\begin{tabular}{|l|l|l|l|l|}
\hline Input & Base & Units $^{-1}$ & Optimistic & Pessimistic \\
\hline Working days per year & 300 & Days year $^{-1}$ & 360 & 240 \\
\hline 8-hour shifts per day & 3 & Shifts day $^{-1}$ & 3 & 3 \\
\hline Unpaid breaks per shift & 1 & Hours shift $^{-1}$ & 0.5 & 1.5 \\
\hline Paid breaks per shift & 0.75 & Hours shift $^{-1}$ & 0.5 & 1 \\
\hline Building Costs & $\$ 3000$ & $\$ \mathrm{~m}^{-2}$ & 1600 & 4000 \\
\hline
\end{tabular}




\begin{tabular}{|l|l|l|l|l|}
\hline Labor Rate & $\$ 18$ & $\$$ hour $^{-1}$ & $\$ 15$ & $\$ 25$ \\
\hline Building Useful Life & 20 & Years & 20 & 20 \\
\hline Capital Useful Life & 6 & Years & 6 & 6 \\
\hline Discount Rate & $10 \%$ & $\%$ & $10 \%$ & $10 \%$ \\
\hline Auxiliary Equipment Cost & $10 \%$ & $\%$ of main machine cost & $10 \%$ & $10 \%$ \\
\hline Maintenance & $10 \%$ & $\%$ of main machine cost & $5 \%$ & $15 \%$ \\
\hline Fixed Overhead & $33 \%$ & $\begin{array}{l}\text { \% of main machine, building, } \\
\text { aux. equip, and maintenance cost }\end{array}$ & $30 \%$ & $35 \%$ \\
\hline Energy Cost & $3 \%$ & $\%$ of material and labor cost & $3 \%$ & $3 \%$ \\
\hline
\end{tabular}

Table 2: Facility-wide model parameters and sensitivity ranges

Production volumes are adjusted to account for both yield and scrap losses within specific steps, and the increase in production volumes to account for these losses is carried upstream throughout the entire manufacturing process. Table 3 lists the yield rates for each of the materials, along with the associated manufacturing step.

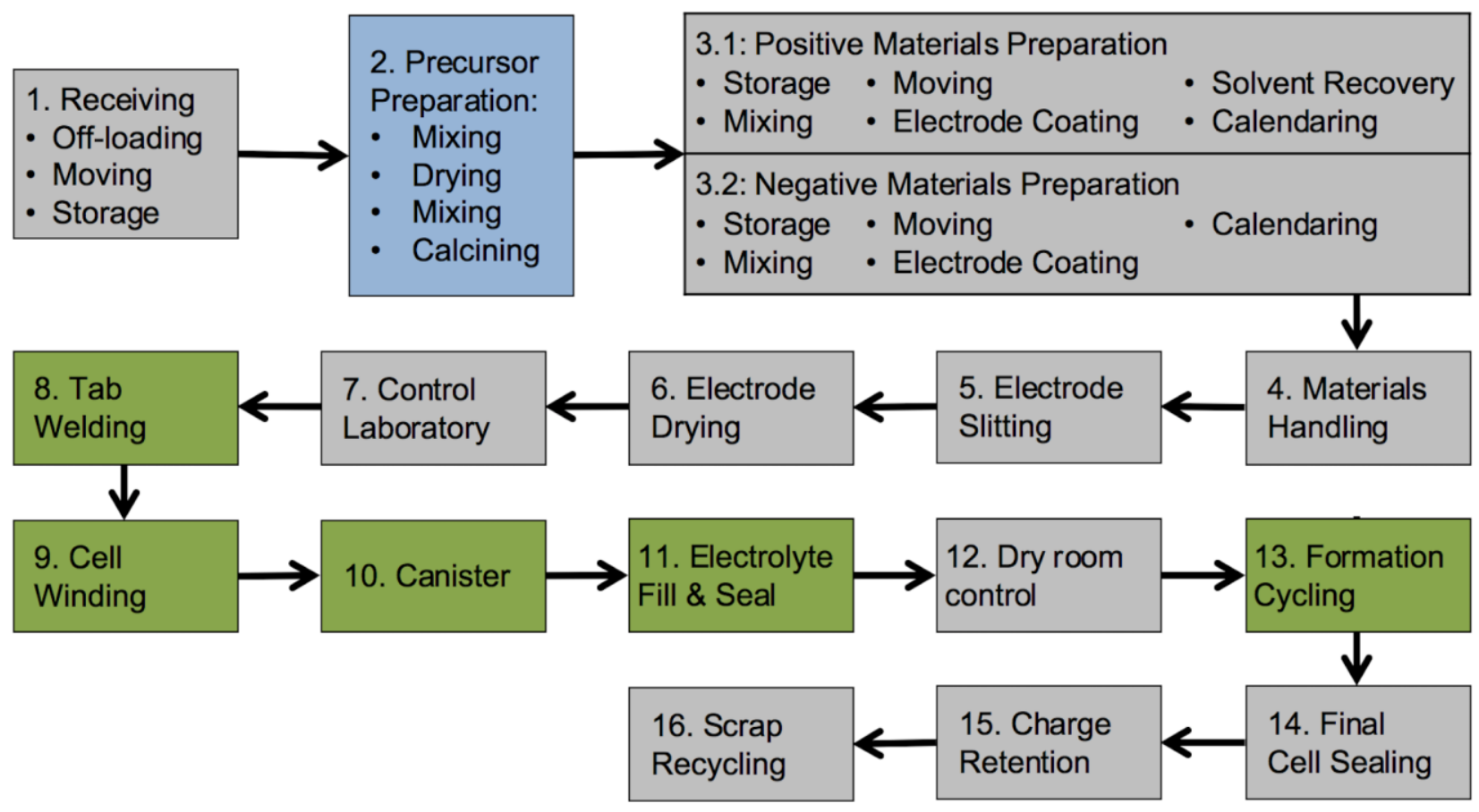

Figure 2: Cylindrical cell manufacturing steps. Steps in gray are common to all lithium ion cell formats and taken from $\mathrm{BatPaC}$ estimates, steps in green are unique to cylindrical cells and so have been modified from the $\mathrm{BatPaC}$ model. The precursor preparation step (in blue) is common 
to all cell formats, and replaces $\mathrm{BatPaC}$ assumptions about purchasing premixed cathode materials.

\begin{tabular}{|l|l|l|}
\hline & Yield Rate & Step \\
\hline Cathode Material & $92.2 \%$ & $\begin{array}{l}\text { 3.1 Cathode material } \\
\text { mixing }\end{array}$ \\
\hline Anode Material & $92.2 \%$ & $\begin{array}{l}\text { 3.2 Anode material } \\
\text { mixing }\end{array}$ \\
\hline Cathode Foil & $90.2 \%$ & 3.1 Cathode coating \\
\hline Anode Foil & $90.2 \%$ & 3.2 Anode coating \\
\hline $\begin{array}{l}\text { Solvent } \\
\text { Recovery }\end{array}$ & $99.5 \%$ & 3.1 Cathode Coating \\
\hline Separators & $98 \%$ & 9 Cell Winding \\
\hline Electrolyte & $94 \%$ & 11 Electrolyte Fill \& Seal \\
\hline Cells & $\begin{array}{l}95 \% \\
90-99 \%\end{array}$ & 15 Charge Retention \\
\hline
\end{tabular}

Table 3: Material yield rates and associated manufacturing steps

\subsubsection{Cylindrical cell steps}

For the cylindrical-cell specific steps, we contacted a number of equipment

manufacturers to obtain specific information about the machinery necessary for these steps.

These estimates included equipment prices, footprint, process rates, and information on labor, and whether there are specific tooling requirements. These estimates are included in Table 4 .

\begin{tabular}{|c|c|c|c|c|c|c|}
\hline Step & $\begin{array}{l}\text { Equipment } \\
\text { Cost } \\
\text { (millions of } \\
\$ \text { ) }\end{array}$ & $\begin{array}{l}\text { Footprint } \\
\text { (m2) }\end{array}$ & $\begin{array}{l}\text { Fraction } \\
\text { al use of } \\
\text { labor }\end{array}$ & Process rate & $\begin{array}{l}\text { Unplan } \\
\text { ned } \\
\text { Downti } \\
\text { me }\end{array}$ & $\begin{array}{l}\text { Dedicat } \\
\text { ed } \\
\text { (Yes/No }\end{array}$ \\
\hline 1 Receiving & 3.6 & 900 & 3 & $6667 \mathrm{~kg} \mathrm{shift}^{-1}$ & $20 \%$ & Yes \\
\hline \multicolumn{7}{|l|}{2 Precursor preparation } \\
\hline Mixing & 0.55 & 200 & 0.67 & $10001 \mathrm{shift}^{-1}$ & $25 \%$ & Yes \\
\hline Drying & $\begin{array}{c}1.5 \\
1.2-1.8 \\
\end{array}$ & $\begin{array}{c}22 \\
20-25 \\
\end{array}$ & 1 & $\begin{array}{l}351 \mathrm{hr}^{-1} \\
29-44 l \mathrm{lhr}^{-1}\end{array}$ & $25 \%$ & Yes \\
\hline Mixing & 0.55 & 200 & 0.67 & $10001 \mathrm{shift}^{-1}$ & $25 \%$ & Yes \\
\hline Calcining & $\begin{array}{c}1.5 \\
1.2-1.8 \\
\end{array}$ & $\begin{array}{c}22 \\
20-25 \\
\end{array}$ & 1 & $\begin{array}{l}201 \mathrm{hr}^{-1} \\
15-30 l \mathrm{hr}^{-1}\end{array}$ & $25 \%$ & Yes \\
\hline \multicolumn{7}{|c|}{ 3.1 Positive materials preparation } \\
\hline Cathode material storage & 1.1 & 200 & 0.67 & 10001 shift $^{-1}$ & $25 \%$ & Yes \\
\hline Cathode material mixing & 0.55 & 200 & 0.67 & $10001 \mathrm{shift}^{-1}$ & $25 \%$ & Yes \\
\hline Cathode material moving & 0.55 & 750 & 4 & 10001 shift $^{-1}$ & $25 \%$ & Yes \\
\hline
\end{tabular}




\begin{tabular}{|c|c|c|c|c|c|c|}
\hline Cathode coating & 8.7 & 750 & 4 & $15 \mathrm{~m}^{2} \mathrm{~min}^{-1}$ & $30 \%$ & Yes \\
\hline Solvent Recovery & 3.3 & 225 & 2 & $212 \mathrm{~kg} \mathrm{hr}^{-1}$ & $20 \%$ & Yes \\
\hline Cathode calendaring & 1.1 & 225 & 0.67 & $15 \mathrm{~m}^{2} \min ^{-1}$ & $30 \%$ & Yes \\
\hline \multicolumn{7}{|c|}{ 3.2 Negative materials preparation } \\
\hline Anode material storage & 1.1 & 200 & 0.67 & 9001 shift $^{-1}$ & $25 \%$ & Yes \\
\hline Anode material mixing & 0.55 & 200 & 0.67 & 9001 shift $^{-1}$ & $25 \%$ & Yes \\
\hline Anode coating & 8.7 & 750 & 4 & $15 \mathrm{~m}^{2} \mathrm{~min}^{-1}$ & $30 \%$ & Yes \\
\hline Anode calendaring & 1.1 & 225 & 1 & $15 \mathrm{~m}^{2} \min ^{-1}$ & $30 \%$ & Yes \\
\hline 4 Materials handling & 1.6 & 900 & 4 & $19 \mathrm{~m}^{2} \min ^{-1}$ & $20 \%$ & Yes \\
\hline 5 Electrode slitting & 2.2 & 300 & 4 & $19 \mathrm{~m}^{2} \min ^{-1}$ & $20 \%$ & Yes \\
\hline 6 Electrode drying & 0.2 & 38 & 0.25 & $600 \mathrm{~kg} \mathrm{shift}^{-1}$ & $20 \%$ & Yes \\
\hline 7 Control laboratory & 1.6 & 300 & 4 & $121 \mathrm{kWh} \mathrm{hr}^{-1}$ & $20 \%$ & Yes \\
\hline 8 Tab welding* $\dagger$ & $\begin{array}{c}0.13 \\
0.12-0.15\end{array}$ & $\begin{array}{c}6 \\
5-7 \\
\end{array}$ & 1 & $\begin{array}{l}30 \text { cells } \mathrm{min}^{-1} \\
25-35 \text { cells } \mathrm{min}^{-1}\end{array}$ & $20 \%$ & Yes \\
\hline 9 Cell winding $* \dagger$ & $\begin{array}{c}0.42 \\
0.25-0.59\end{array}$ & $\begin{array}{c}5 \\
4-5 \\
\end{array}$ & 1 & $\begin{array}{l}15 \text { cells } \mathrm{min}^{-1} \\
12-20 \text { cells } \mathrm{min}^{-1}\end{array}$ & $20 \%$ & Yes \\
\hline 10 Canister insertion $* \dagger$ & $\begin{array}{c}0.63 \\
0.25-1\end{array}$ & $\begin{array}{c}5 \\
4-5\end{array}$ & 1 & $\begin{array}{l}35 \text { cells } \mathrm{min}^{-1} \\
30-40 \text { cells } \mathrm{min}^{-1}\end{array}$ & $20 \%$ & Yes \\
\hline 11 Electrolyte fill \& seal $* \dagger$ & $\begin{array}{c}0.58 \\
0.15-1\end{array}$ & $\begin{array}{c}2 \\
1-2\end{array}$ & 1 & $\begin{array}{l}60 \text { cells } \mathrm{min}^{-1} \\
30-120 \text { cells } \mathrm{min}^{-}\end{array}$ & $20 \%$ & Yes \\
\hline 12 Dry room control & 22 & 100 & 2 & $0.03 \mathrm{~m}^{2} \mathrm{~m}^{-2}$ & $0 \%$ & No \\
\hline 13 Formation cycling* & $\begin{array}{c}0.2 \\
0.13-0.25\end{array}$ & 4 & 0.23 & $\begin{array}{l}31.25 \text { cells hour }^{-1} \\
31.25 \mathrm{cells}^{-1} r^{-1}- \\
62.5 \mathrm{cells} \mathrm{rr}^{-1}\end{array}$ & $20 \%$ & Yes \\
\hline 14 Final cell sealing & 2.2 & 450 & 2 & 30 cells $\min ^{-1}$ & $20 \%$ & Yes \\
\hline 15 Charge retention & 0.01 & 1.2 & 0.004 & $\begin{array}{l}1000 \text { cells/336 } \\
\text { hours }\end{array}$ & $20 \%$ & Yes \\
\hline 16 Scrap recycling & 2.7 & 600 & 5 & $441 \mathrm{~kg} \mathrm{shift}^{-1}$ & $20 \%$ & Yes \\
\hline
\end{tabular}

* Assumptions specific to cylindrical cells

$\dagger$ Steps enclosed in dry room control system, which is sized based on the building area required for these steps

Table 4: Equipment, area, labor, and process rate assumptions for each manufacturing step.

BatPaC point estimates are used for each of the steps common for all lithium ion cell formats.

Uncertainty bounds for the cylindrical-specific and precursor preparation steps are included below the baseline estimate.

\subsubsection{Precursor Mixing}

The precursor mixing step calculations included assumptions about the specific precursor materials used, the costs of the precursor materials used, and the machinery and equipment 
necessary for this type of processing. Because of the steps and processes involved, it is very common for battery producers to outsource these steps to another company. However, doing so does increase the materials cost because of the additional markup that producers pay for the convenience of finalized active materials. Including an assessment of the in-house costs provides a better estimate of the true cost floor of battery manufacturing.

For the precursor material costs themselves, we used historical price data from the USGS 2015 Mineral Commodity Summary for each of the key constituent parts. The lithium price data listed is specifically based on lithium carbonate data (because of its dominance in the global market). For the other elements (Ni, $\mathrm{Co}, \mathrm{Al}, \mathrm{Mn})$, we assumed that the price per unit mass of the constituent compound was determined entirely by the active element in the constituent compound. For example, the 5-year average nickel price is $\$ 19 \mathrm{~kg}^{-1}, \mathrm{NiSO}_{4}$ is $38 \%$ nickel by mass, so we assumed the cost per $\mathrm{kg}$ of $\mathrm{NiSO}_{4}$ to be $\$ 7 \mathrm{~kg}^{-1}$. Similar calculations were done for the other precursor materials, but we did correct for the impurity of the manganese prices quoted in the USGS data.

The steps and machinery required for precursor mixing depended on the specific chemistry. For both NMC and NCA, the cathode materials are prepared using a mixed hydroxide method, where the nickel, manganese, and cobalt compounds are pre-mixed and dried before adding lithium. [13,14] The lithium compounds are then mixed with the hydroxide or oxide materials and calcined. For both mixing steps in the precursor preparation process, we used the assumptions listed for mixing equipment in the $\mathrm{BatPaC}$ model. For both the drying and calcining steps, we sourced quotes from manufacturers on both price and energy consumption for the required different operating temperatures. The equipment price, area requirements, labor 
requirements, and process rate are listed in Table 4. Additional assumptions about the drying and calcining processes are detailed in Table 5.

\begin{tabular}{|l|c|c|}
\hline & Drying* & Calcining \\
\hline Furnace length & \multicolumn{2}{|c|}{15 feet } \\
\hline Temperature $\left({ }^{\circ} \mathrm{C}\right)$ & 100 & 800 \\
\hline Cycle time (hours) & $\begin{array}{c}10 \\
(8-12)\end{array}$ & $\begin{array}{c}18 \\
(12-24)\end{array}$ \\
\hline Power consumption $(\mathrm{kW})$ & $\begin{array}{c}70 \\
(63-77)\end{array}$ & $\begin{array}{c}200 \\
(180-220)\end{array}$ \\
\hline
\end{tabular}

*NCA and NMC precursor manufacturing only

Table 5: Precursor drying and calcining process assumptions

The power consumption values listed in Table 5 were used to calculate the additional cost of energy associated with precursor mixing. This step is fairly energy intensive, and the BatPaC assumption of energy costs (3\% of the total material and labor cost) both excludes these steps and is not representative of the energy requirements of drying and calcining the precursor materials. Energy consumption for the mixing steps is negligible compared to the energy required for drying and calcining, and is excluded. The additional energy consumption is calculated based on the number of hours per year the machinery is operated for, and with an assumed electricity price of $\$ 0.07 \mathrm{kWh}^{-1}$, the median price of electricity for industrial customers in 2015. [15]

\subsubsection{Cell hardware costs}

Cell canister costs were based on inflation-adjusted unit costs of the cell container $(\$ 0.22$ per cell), but did not include additional expenses that result from additional mass. The positive and negative terminal assemblies for cylindrical cells differ slightly. One terminal, in this case, the negative terminal, uses the cell canister as the current conductor. There is also a polymer insulator inside the cell.[16] This insulator costs on the order of $\$ 0.05-\$ 0.10$ per cell. The other terminal, in this case the positive terminal, include a polymer insulator and current interrupting 
device, in addition to a separate metallic cap. The cost of this terminal assembly is on the order of $\$ 0.10-\$ 0.20$ per cell. The safety devices are a substantial contributor to the assembly cost, and the cap contributes $<\$ 0.05$ per cell.[17] This puts the positive terminal assembly at a slightly lower cost estimate than the unit cost for prismatic cell terminals assumed in BatPaC.

\section{Results and discussion}

\subsection{Cathode Material Costs}

When we account for all of the materials purchased, equipment, labor, and energy inputs required for each of the cathode active materials, we find that our estimates are lower than the assumed values in other models. Table 6 lists our costs per $\mathrm{kg}$, with comparisons to other assumed values. Our values are consistent with the elimination of a markup to the purchase price from an outside supplier, and with informal comparisons to the prices quoted by other battery manufacturers.

\begin{tabular}{|l|c|c|}
\hline Battery Chemistry & Precursor PBCM & BatPaC assumed values \\
\hline \multirow{2}{*}{ LMO } & $\$ 3.75$ & $\$ 10.9$ \\
& $(\$ 2.60-\$ 5.36)$ & $(\$ 8.72-\$ 21.8)$ \\
\hline \multirow{2}{*}{ NMC } & $\$ 21.43$ & $\$ 28.34$ \\
& $(\$ 16.89-\$ 27.43)$ & $(\$ 28.34-\$ 31.61)$ \\
\hline \multirow{2}{*}{ NCA } & $\$ 26.17$ & $\$ 35.97$ \\
& $(\$ 21.53-\$ 31.98)$ & $(\$ 35.97-\$ 40.33)$ \\
\hline
\end{tabular}

Table 6: Cathode active material costs per kg with uncertainty bounds, $2015 \$$

\subsection{Unit Costs}

Comparing the manufacturing costs of the baseline 18650 cell with $70 \mu \mathrm{m}$ electrodes and $2 \mathrm{GWh}$ of storage capacity produced annually, we find that the cost per cell is lowest for LMO cells (as shown in Figure 3). However, when we examine the cost on a per kWh basis, the LMO cells are significantly more expensive than both other chemistries we examine. While the active materials needed per cell are less expensive, the number of cells required to produce $2 \mathrm{GWh}$ of 
storage capacity is roughly double the number of NCA or NMC cells necessary to store the same amount of energy. This cost pattern holds regardless of the production volume, as Figure 4 shows. The figure also shows that economies of scale of the production are largely reached at volumes of $1 \mathrm{GWh}$ year ${ }^{-1}$ with limited reductions in cost at higher volumes. Additional detail about the uncertainty in the cost estimates is provided in the supplementary information.

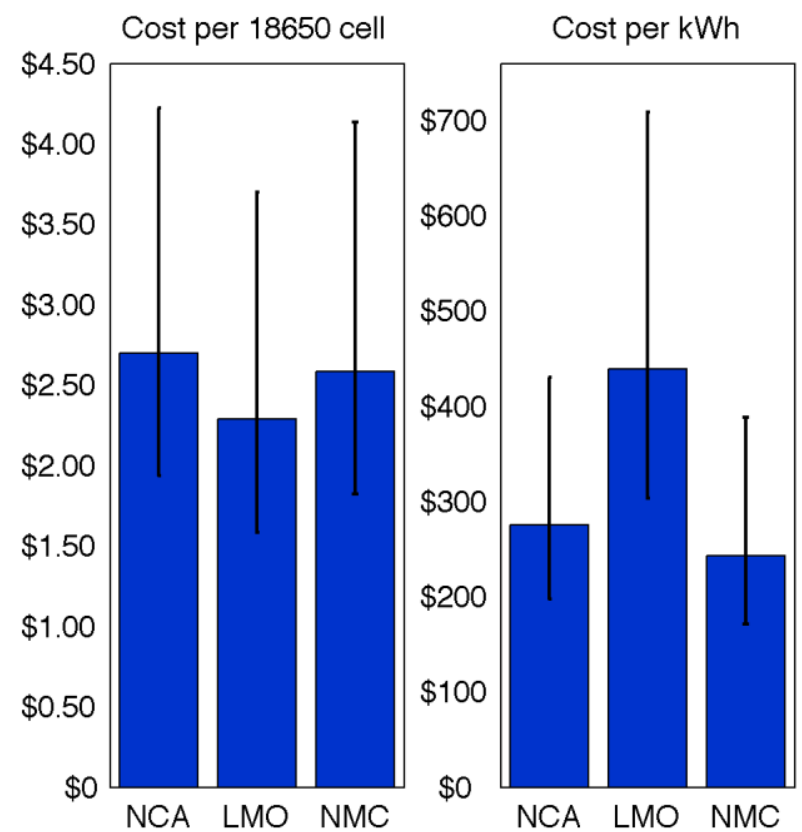

Figure 3: cost per cell and per kWh for NCA, LMO, and NMC batteries, assuming 18650 cells, $70 \mu \mathrm{m}$ electrodes, and $2 \mathrm{GWh}$ of annual production 


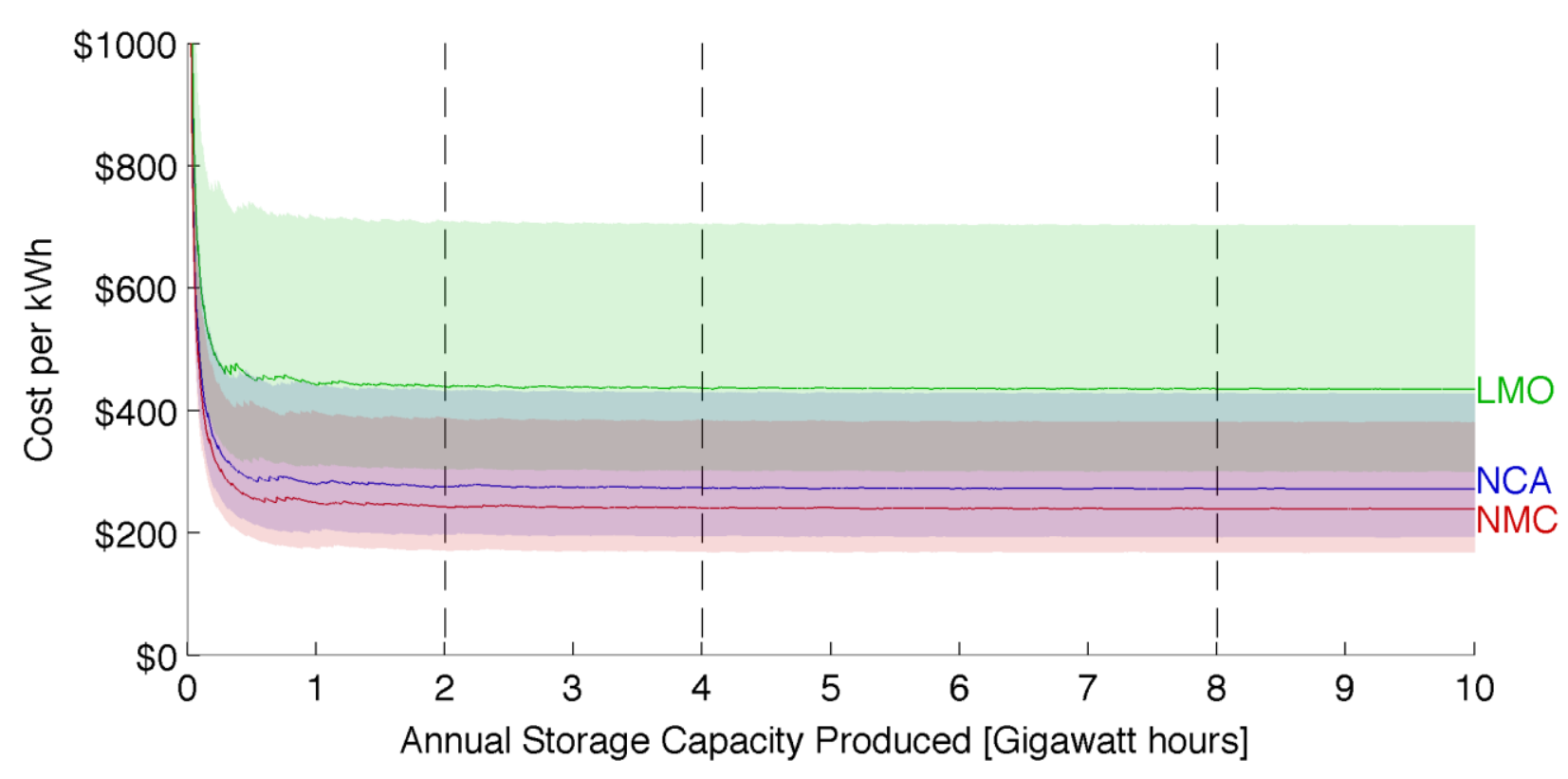

Figure 4: Cost per kWh of NCA, NMC, and LMO batteries generally reach economies of scale at $1 \mathrm{GWh}$ of annual production, and remain stable as the annual production volumes increases. Production volumes used in later sensitivity analyses ( $2 \mathrm{GWh}, 4 \mathrm{GWh}$, and $8 \mathrm{GWh})$ are highlighted.

\subsection{Sensitivity Analysis}

Because of the inefficiency of LMO batteries in this cylindrical format, we focus our further analysis on NCA and NMC chemistries. Figure 5 is a tornado plot that shows how the cost per kWh of storage capacity changes as we vary the model parameters specified. For both chemistries, we find that only decreasing the electrode thickness (from $70 \mu \mathrm{m}$ to $50 \mu \mathrm{m}$ ) is the only change that results in a higher price per $\mathrm{kWh}$, as more of the battery volume is occupied by separators and current collectors instead of active material. While the per $\mathrm{kWh}$ cost increases with these thinner electrodes, this can be desirable in applications where a high power density battery is required, as is the case in PHEVs. Increasing the thickness (from $70 \mu \mathrm{m}$ to $100 \mu \mathrm{m}$ ), changing the format of the battery to be taller or wider (or both), and doubling or quadrupling 
annual production volumes all decrease the cost per $\mathrm{kWh}$. However, none of these changes is alone sufficient to reach the DOE energy storage target of $\$ 125 \mathrm{kWh}^{-1}$. Even in the most optimistic scenario, when the cells are the largest (20720), electrodes the thickest $(100 \mu \mathrm{m})$, and the production volume is $8 \mathrm{GWh}$ per year, the cost per kWh is well above the DOE target of $\$ 125 \mathrm{kWh}^{-1}$ : the NCA cells are $\$ 206 \mathrm{kWh}^{-1}$ and NMC cells are $\$ 180 \mathrm{kWh}^{-1}$.

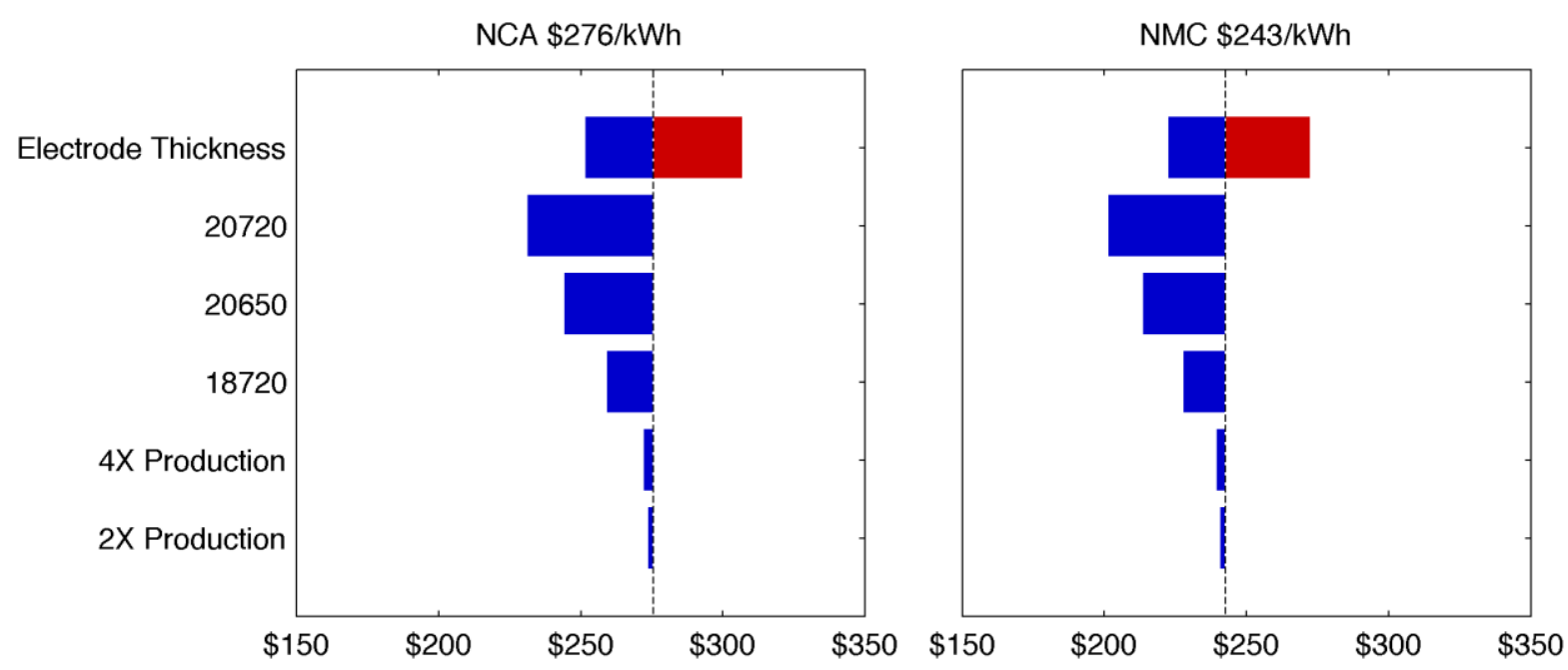

Figure 5: Change in cost per kWh for NCA and NMC batteries as production volumes, cell dimensions, and electrode thicknesses vary $(50 \mu \mathrm{m}$ to $100 \mu \mathrm{m})$.

\subsection{Cost Breakdown}

For both our baseline model (18650 cells, $70 \mu \mathrm{m}$ electrodes, and $2 \mathrm{GWh}$ of production year $^{-1}$ ) and the most optimistic (20720 cells, $100 \mu \mathrm{m}$ electrodes, and $8 \mathrm{GWh}$ of production year ${ }^{-1}$ ) combination of parameters, we find that the total cost is dominated by materials costs, which account for roughly $40 \%$ of the cost per kWh. Figure 6 shows the cost breakdown for both NCA and NMC cells in the baseline and most optimistic combinations of model parameters. 


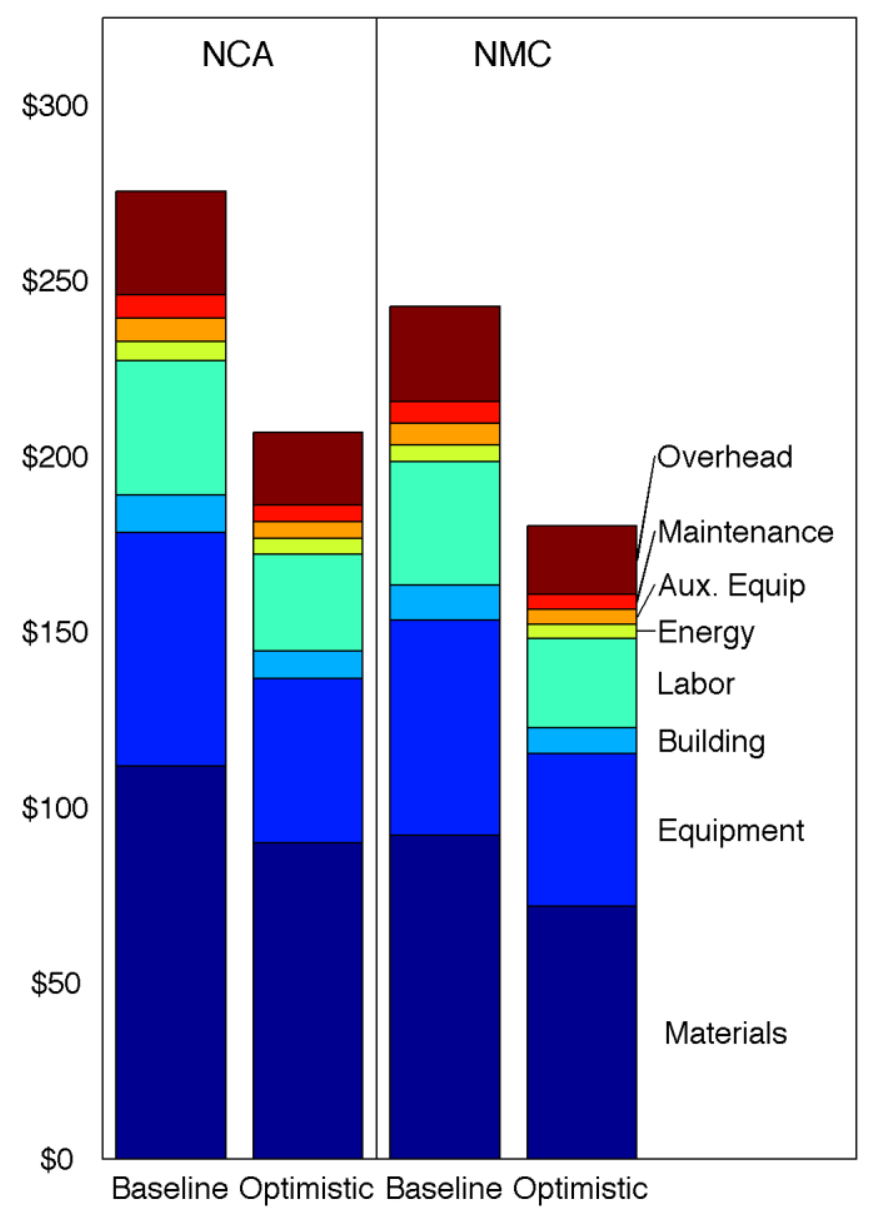

Figure 6: Per kWh baseline and optimistic cost breakdowns for NCA and NMC cells. Materials account for roughly $40 \%$ of the total cost.

The dominance of material cost is also evident when we examine the costs per $\mathrm{kWh}$ associated with each step in the manufacturing process. Figure S3 (included in the Supplementary information) shows the most expensive steps (each with a cost of more than $\$ 5$ $\mathrm{kWh}^{-1}$ ) for manufacturing the baseline 18650 cells with either an NMC or NCA cathode. In both cases, we see that materials play a substantial role in the overall cost of many of these steps. Processes that have a long cycle time -formation cycling and charge retention -are also costly. 
The data also shows that many of the most expensive steps are associated with cell structural materials. Figure 7 breaks down the materials costs for both chemistries and baseline and optimistic scenarios. Nearly half of the materials cost is associated with cell hardware, including the container and terminal assemblies. These materials have been used in massproduced cylindrical batteries (both primary and secondary) for decades, and are unlikely to have further cost reductions from large-scale production. Cathode precursor materials account for $27 \%$ of material costs for NCA baseline, $20 \%$ for NMC baseline, and play a larger role for larger cells with higher production volumes, where cell hardware, which scales by a combination of the number of pieces and size, contributes less to the cost per $\mathrm{kWh}$.

It is important to note that these material costs are not driven by the price of lithium. Previous analysis shows that the price of lithium carbonate, the main source of lithium for batteries, has little impact on the overall cost of prismatic batteries, even if commodities prices undergo significant fluctuations. [18] This holds for cylindrical cells as well: even if the price of lithium carbonate increases to $\$ 25 \mathrm{~kg}^{-1}$ (from the baseline value of $\$ 7.50$ ), lithium never accounts for more than $10 \%$ of the total cell cost per $\mathrm{kWh}$, and the resulting change in the cost per $\mathrm{kWh}$ is always below $10 \%$, as shown in Table 7 .

\begin{tabular}{|l|c|c|c|c|c|c|c|c|}
\hline Scenario & \multicolumn{3}{|c|}{$18650,70 \mu \mathrm{m}, 2 \mathrm{GWh}$} & \multicolumn{3}{c|}{$20720,100 \mu \mathrm{m}, 8 \mathrm{GWh}$} \\
\hline Chemistry & \multicolumn{2}{|c|}{ NCA } & \multicolumn{2}{c|}{ NMC } & \multicolumn{2}{c|}{ NCA } & \multicolumn{2}{c|}{ NMC } \\
\hline $\mathrm{Li}_{2} \mathrm{CO}_{3}$ Price $\left[\$ \mathrm{~kg}^{-1}\right]$ & $\$ 7.50$ & $\$ 25$ & $\$ 7.50$ & $\$ 25$ & $\$ 7.50$ & $\$ 25$ & $\$ 7.50$ & $\$ 25$ \\
\hline Cost of $\mathrm{Li}_{2} \mathrm{CO}_{3} \mathrm{kWh}^{-1}$ & $\$ 6.10$ & $\$ 20.30$ & $\$ 5.60$ & $\$ 18.66$ & $\$ 6.10$ & $\$ 20.30$ & $\$ 5.60$ & $\$ 18.66$ \\
\hline Percentage of materials cost & $5 \%$ & $16 \%$ & $5 \%$ & $18 \%$ & $7 \%$ & $19 \%$ & $8 \%$ & $22 \%$ \\
\hline Percentage of overall cost & $2 \%$ & $6 \%$ & $2 \%$ & $7 \%$ & $3 \%$ & $8 \%$ & $3 \%$ & $10 \%$ \\
\hline Change in Cost $\mathrm{kWh}^{-1}$ & - & $+5 \%$ & - & $+6 \%$ & - & $+7 \%$ & - & $+7 \%$ \\
\hline
\end{tabular}

Table 7: Impact of lithium prices on NCA and NMC cells in baseline and optimistic scenarios 


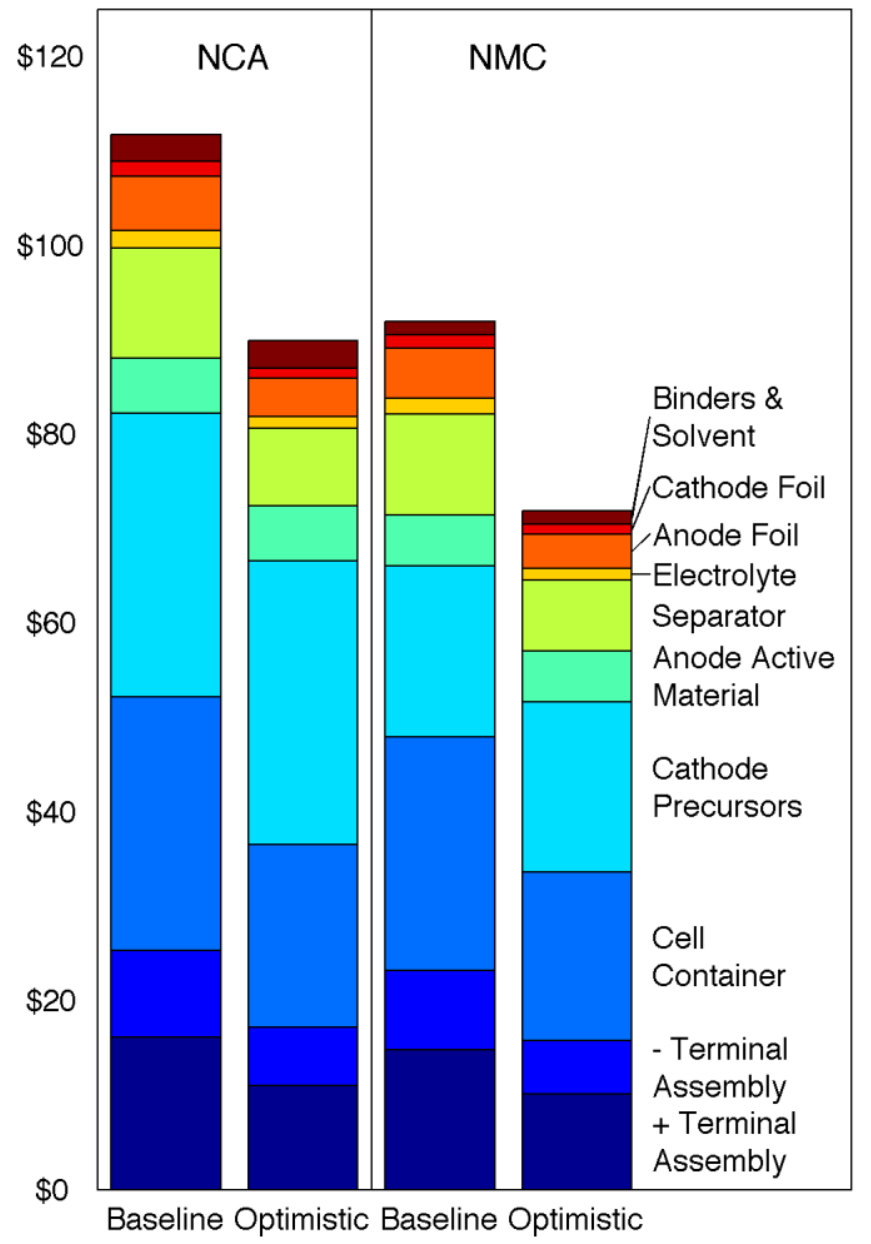

Figure 7: Per kWh material cost breakdown for NCA and NMC cells

Figure 8 compares both the baseline and optimistic cost breakdowns for all 3 chemistries to prismatic cells with roughly 25 Ah of capacity. The exact prismatic cell dimensions and bill of materials is determined using BatPaC (version 4, May 2015), with three modifications. 1) We allowed the maximum electrode thickness constraint to increase to $200 \mu \mathrm{m}, 2$ ) we reduced the power requirement on the cells and 3) the specific capacities of the cathode materials was updated to match the assumptions included in Table 1. Costs are calculated using a processbased cost model adapted from Sakti et al with conversions to $2015 \$$ and using in-house precursor preparation. Specific information about the prismatic cell dimensions is provided in the supplementary information. 
For all three battery chemistries, the cost per kWh for larger prismatic cells is lower than the cost for both types of cylindrical cells. This is consistent with previous analysis of the cost of prismatic LMO cells, which also showed that larger formats can offer reduced costs, even when electrodes are not allowed to increase to $200 \mu \mathrm{m}$.[18] Although the overall cost per kWh decreases, the cost of electrode materials per kWh increases slightly as larger amounts are scrapped per cell when there are manufacturing defects in prismatic cells. This effect is most pronounced when the overall annual storage capacity produced and the capacity of each cell is similar in magnitude. Overall, reduced hardware costs associated with larger cells more than offset the additional expense. Details about the material cost differences between the 18650 cells and prismatic cells are shown for NCA cells in Figure S4. It is also important to note that both of the NCA and NMC batteries are not able to deliver electricity at high power because of the relatively small electrode surface area relative to the thickness of the electrodes. The lower costs for prismatic cells persists even when purchased cathode materials are used instead of lower-cost in-house production, as shown in Figure S5. 


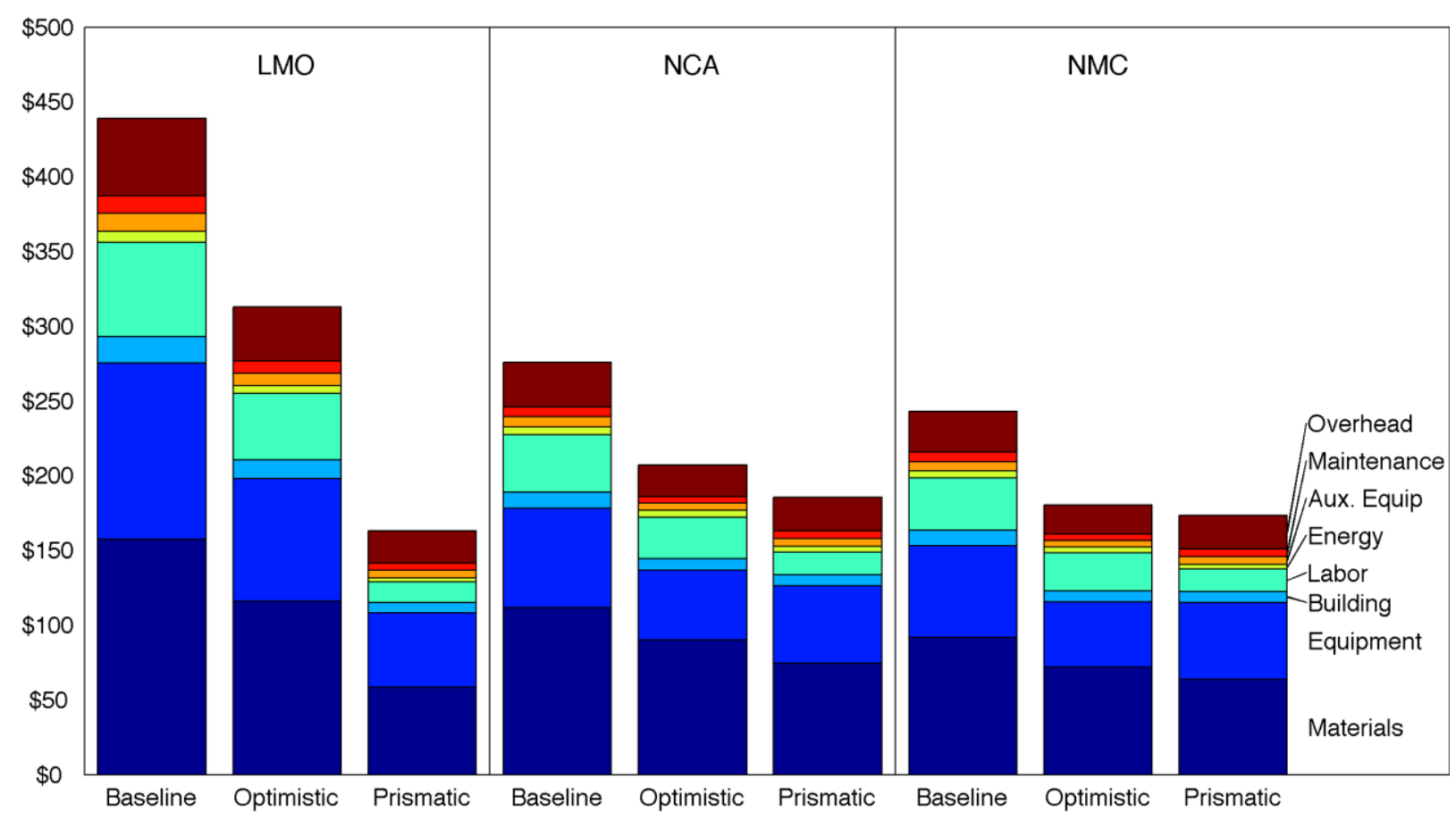

Figure 8: per kWh cost breakdown comparison for baseline 18650 cylindrical cells, optimistic 20720 cylindrical cells, and BatPaC prismatic cells

\section{Conclusions}

The process-based cost model we construct for cylindrical lithium-ion cells shows that the cell chemistry has a significant impact on the per kWh cost of the batteries. For LMO batteries, with a low specific energy, the cylindrical cell format is too small and does not allow for the electrode thickness to increase sufficiently. As a result, additional cells are required to meet a specified energy storage production target. Prismatic LMO cells, which offer more opportunities for large cell formats with thicker electrodes and reduced hardware costs per kWh offer more opportunity for future cost reductions.

Both NMC and NCA cylindrical batteries are less expensive per kWh to manufacture than LMO cylindrical cells, and further cost reductions are possible by increasing the cylindrical cell dimensions and the electrode thickness. 
While initial cost savings are possible from increasing production volumes, the possibility for cost reductions from scale alone are minimal past $1 \mathrm{GWh}$ of annual production, a volume which large battery manufacturers have already surpassed. At these higher production volumes materials play a significant role in the cost of energy storage per $\mathrm{kWh}$, accounting for roughly half of the overall expenses.

Cathode material costs can be reduced by producing them from precursors in-house instead of purchasing them from suppliers. LMO is subject to the highest markup, at almost $200 \%$, but the markup for NCA and NMC have substantial impacts on the cost per kWh as well. Like prismatic cells, lithium prices play a small role in the cost of NMC and NCA cylindrical cells. A more than $200 \%$ increase in the price of lithium carbonate leads to a less than $10 \%$ increase in the cost per $\mathrm{kWh}$ for each of the cell configurations considered.

Cell hardware is a significant contributor to the overall material cost per $\mathrm{kWh}$. Prismatic cells, which have more design flexibility to account for specific chemistry characteristics, can be larger, requiring less hardware per $\mathrm{kWh}$ and reducing costs. This reduction is most pronounced for LMO prismatic cells, which can be manufactured for less than half the cost of cylindrical LMO cells. There is also potential for reducing the manufacturing cost for NCA and NMC cells using a prismatic format, but the cells produced with that format are more rate-limited than LMO counterparts.

\section{Acknowledgements}

The authors would like to thank Erica Fuchs and Jeremy Michalek for their early discussions and guidance about process-based cost modeling. This material is based upon work supported by the National Science Foundation Graduate Research Fellowship under Grant No. DGE 1252522. Any opinion, findings, and conclusions or recommendations expressed in this 
material are those of the authors(s) and do not necessarily reflect the views of the National

Science Foundation.

\section{References}

[1] A.A. Akhil, G. Huff, A.B. Currier, B.C. Kaun, D.M. Rastler, S.E.B. Chen, et al., DOE/EPRI 2013 Electricity Storage Handbook, Sandia National Laboratories, 2013.

[2] P. Nelson, K. Gallagher, I. Bloom, BatPaC, Argonne National Laboratory. (n.d.). http://www.cse.anl.gov/batpac/download.php.

[3] P.A. Nelson, K.G. Gallagher, I. Bloom, D.W. Dees, Modeling the Performance and Cost of Lithium-Ion Batteries for Electric-Drive Vehicles, 2012.

[4] D.L. Wood III, J. Li, C. Daniel, Prospects for reducing the processing cost of lithium ion batteries, Journal of Power Sources. 275 (2014) 234-242. doi:10.1016/j.jpowsour.2014.11.019.

[5] A. Sakti, J.J. Michalek, E.R.H. Fuchs, J.F. Whitacre, A techno-economic analysis and optimization of Li-ion batteries for light-duty passenger vehicle electrification, Journal of Power Sources. 273 (2014) 966-980. doi:10.1016/j.jpowsour.2014.09.078.

[6] B. Nykvist, M. Nilsson, Rapidly falling costs of battery packs for electric vehicles, Nature Climate Change. 5 (2015) 329-332. doi:10.1038/nclimate2564.

[7] A. Sakti, I.M.L. Azevedo, E.R.H. Fuchs, J.J. Michalek, K.G. Gallagher, J.F. Whitacre, A new framework for technology forecasting: the case of Li-ion batteries for plug-in electric vehicles, Social Science Research Network. (n.d.).

[8] A. Sakti, I.M.L. Azevedo, E.R.H. Fuchs, J.J. Michalek, K. Gallagher, J.F. Whitacre, A new framework for technology forecasting: the case of Li-ion batteries for plug-in electric vehicles, (2015) 1-56.

[9] K. Nakura, K. Ariyoshi, H. Yoshizawa, T. Ohzuku, Characterization of Lithium Insertion Electrodes and Its Verification: Prototype 18650 Batteries Consisting of LTO and LAMO, Journal of the Electrochemical Society. 162 (2015) A622-A628. doi:10.1149/2.0361504jes.

[10] N.S. Ong, Manufacturing cost estimation for PCB assembly: An activity-based approach, International Journal of Production Economics. 38 (n.d.) 159-172.

[11] J. La Trobe-Bateman, D. Wild, Design for manufacturing: use of a spreadsheet model of manufacturability to optimize product design and development, Research in Engineering Design. (2003). doi:10.1007/s00163-003-0030-8.

[12] C. Bloch, R. Ranganathan, Process-Based Cost Modeling, IEEE Transactions on Components, Hybrids, and Manufacturing Technology. 15 (1992) 288-294.

[13] J.M. Paulsen, J.R. Dahn, $\mathrm{O}_{2}$-Type $\mathrm{Li}_{2 / 3}\left[\mathrm{Ni}_{1 / 3} \mathrm{Mn}_{2 / 3}\right] \mathrm{O}_{2}$ : A New Layered Cathode Material for Rechargeable Lithium Batteries, Journal of the Electrochemical Society. 147 (n.d.) 2478-2485.

[14] G. Majeau-Bettez, T.R. Hawkins, A.H. Strømman, Life Cycle Environmental Assessment of Lithium-Ion and Nickel Metal Hydride Batteries for Plug-In Hybrid and Battery Electric Vehicles, Es\&T. (2011).

[15] Electric Power Monthly, US Energy Information Administration. (2016). http://www.eia.gov/electricity/monthly/epm_table_grapher.cfm?t=epmt_5_3 (accessed June 20, 2016). 
[16] S.I. Kohn, W.A. Hermann, Cell cap assembly with recessed terminal and enlarged insulating gasket, US 8,057,928 B2, 2011.

[17] A.A. Pesaran, G.-H. Kim, K. Smith, E.C. Darcy, Designing Safe Lithium-Ion Battery Packs Using Thermal Abuse Models, in: Lithium Mobile Power, 2008.

[18] R.E. Ciez, J.F. Whitacre, The cost of lithium is unlikely to upend the price of Li-ion storage systems, Journal of Power Sources. 320 (2016) 310-313.

doi:10.1016/j.jpowsour.2016.04.073. 
Figure 1: Historical prices and future cost predictions for lithium ion batteries. Estimates include both cell- and pack-level cost assessments, which is reflected in the significant variability in the cost estimates.

Figure 2: Cylindrical cell manufacturing steps. Steps in gray are common to all lithium ion cell formats and taken from BatPaC estimates, steps in green are unique to cylindrical cells and so have been modified from the BatPaC model. The precursor preparation step (in blue) is common to all cell formats, and replaces BatPaC assumptions about purchasing premixed cathode materials.

Figure 3: cost per cell and per kWh for NCA, LMO, and NMC batteries, assuming 18650 cells, $70 \mu \mathrm{m}$ electrodes, and $2 \mathrm{GWh}$ of annual production

Figure 4: Cost per kWh of NCA, NMC, and LMO batteries generally reach economies of scale at $1 \mathrm{GWh}$ of annual production, and remain stable as the annual production volumes increases. Production volumes used in later sensitivity analyses ( $2 \mathrm{GWh}, 4 \mathrm{GWh}$, and $8 \mathrm{GWh}$ ) are highlighted.

Figure 5: Change in cost per kWh for NCA and NMC batteries as production volumes, cell dimensions, and electrode thicknesses vary $(50 \mu \mathrm{m}$ to $100 \mu \mathrm{m})$.

Figure 6: Per kWh baseline and optimistic cost breakdowns for NCA and NMC cells. Materials account for roughly $40 \%$ of the total cost.

Figure 7: Per kWh material cost breakdown for NCA and NMC cells

Figure 8: per kWh cost breakdown comparison for baseline 18650 cylindrical cells, optimistic 20720 cylindrical cells, and BatPaC prismatic cells 